Research.

\title{
ANALYSIS OF THE EFFECT OF NET PROFIT MARGIN, RETURN ON ASSETS AND RETURN ON EQUITY ON STOCK PRICE \\ (Case Study on Consumption Industrial Sector Companies Listed in Indonesian Sharia Stock Index at Indonesia Stock Exchange in 2016)
}

\author{
Wartoyo Hadi ${ }^{1,}$, Nurhayati $^{2}$ \\ Department of Management, Economic College of Binaniaga, Bogor, Indonesia \\ toyo_hadi@yahoo.co.id (W. Hadi)
}

*Corresponding author

Received: October 28, 2018; Accepted: November 14, 2018; Published: December 31, 2018

To cite this article: Wartoyo Hadi and Nurhayati. Analysis of The Effect of Net Profit Margin, Return on Assets, and Return on Equity on Stock Price (Case Study on Consumption Industrial Sector Companies Listed in Indonesian Sharia Stock Index at Indonesia Stock Exchange in 2016), The Management Journal of BINANIAGA, Vol. 03, No. 02, December 2018, pp. 81 - 92.

Abstract. This study aims to analyze the effect of Net Profit Margin, Return On Assets, and Return On Equity on Stock Price of consumption industrial sector companies listed in Indonesian Sharia Stock Index at Indonesia Stock Exchange. The method of growth analysis which used is quantitative descriptive method. Whereas to find out the effect of Net Profit Margin, Return On Assets, and Return On Equity for Stock Price partially or simultaneously use descriptive method and multiple linear regression analysis technique. The study results that obtained show that partially Net Profit Margin and Return On Assets do not affect stock price, whereas Return On Equity effects on stock price. Simultaneously Net Profit Margin, Return On Assets, and Return On Equity affect stock prices.

Key words: Net Profit Margin, Return On Assets, Return On Equity, and Stock Price

\section{PREFACE}

The capital market has an important role for economy of a country because a capital market performs two functions. First, as a means for a company to get funds from investors which will be used for business development, additional working capital, and various other company needs. Secondly, it becomes a means for people to invest in financial instruments, such as stocks, bonds, mutual funds, warrants, and others.

Indonesian people, the majority are Muslims, have a choice of products in the capital market in accordance with Islamic law, i.e. Sharia Stock. The institutes for sharia stock are regulations and laws with a fatwa which is used as a reference to form sharia stocks. A fatwa foundation is needed as a basic to form Sharia principles that can be applied in the capital market. The movement of ISSI market capitalization in 2015 reached 2.6 which has decreased from the previous year. In 2012, the Islamic stock market capitalization has only reached 2.4, but at the end of October 2017 it has increased to 3.5 .

A company's financial report is the main source of information used by investors and creditors to make investment decision. Financial ratio analysis can be used as a tool to read, recognize, and understand the meaning of financial statements. So that it can be known various things related to finance and company progress. This shows that financial

Wartoyo Hadi and Nurhayati. Analysis of The Effect of Net Profit Margin, Return on Assets, and Return on Equity on Stock Price (Case Study on Consumption Industrial Sector Companies Listed in Indonesian Sharia Stock Index at Indonesia Stock Exchange in 2016) 
ratio analysis has an effect on changes in stock prices in the capital market which causes over demand or over supply of stocks.

When investing in stocks, it is expected in the future that assets can be developed and give a great profit. The activity of stock is very dynamic following the development of micro and macro economic condition and the company's business performance. The choice of investment at consumption sector can be an alternative portfolio content when other sector investments are still weak because they are resistant to the crisis that occurred a few years ago, where the performance and stock activity weaken but not so significant.

Based on the background, the researcher chose the title "The Effect of Net Profit Margin (NPM), Return on Assets (ROA), and Return on Equity (ROE) on Stock Price (Case Study in Consumption Industry Sector Companies listed in Indonesian Sharia Stock Index ( ISSI) at IDX 2016) ".

\section{The Research Purposes}

1. To find out the effect of Net Profit Margin (NPM) on Stock Price.

2. To determine the effect of Return On Assets (ROA) on Stock Prices.

3. To determine the effect of Return On Equity (ROE) on Stock Prices.

4. To find out the effect of Net Profit Margin (NPM), Return On Assets (ROA), and Return On Equity (ROE) simultaneously on Stock Price in Consumable Industrial Sector Companies listed in the Indonesian Sharia Stock Index (ISSI) at Indonesia Stock Exchange in 2016 .

\section{LITERATURE REVIEW}

Nisrinah and Nisrin, and Sugeng Hariyanto reasearch (Az Zarqa ', Vol. 9, No. 2, December 2017) said that the implementation of Tawheed which is very well applied is a balance of social business aspect, spiritual material and aspects of maintenance utilization."

\section{Stock}

Watung and llat (2016: 520) explained that stock is a piece of paper that shows the rights of investors (the paper owner) to obtain a part of the prospect or organization wealth that issues these securities and various conditions that enable the investor to use his rights. Widuhung $(2014: 146)$ said that sharia stock is an evidence of a company ownership that fulfills sharia principles. Generally, stock can be clarified into 2 types:

1. Preferred stock is a share that provides a fixed dividend and has been stated previously, and claim rights as well when the company is liquidated. Preferred stock can also be converted into ordinary shares. Preferred stock dividend is annuity because it has no due date, then the period is unlimited or a perpetuity.

2. Common stock is a share that has uncertain and not fixed dividend. The rights of common shareholders is generally divided into three; Control Right is used to control the direction of company policy in the General Meeting of Shareholders (GMS), dividend rights, and preemptive rights is the right to buy first when the company issues additional shares.

\section{Stock Price}

Priatinah and Kusuma (2012: 52) explained that stock price is present value of incomes that will be received by investors in the future. The price of a stock in a current market is the market price. Market price is the easiest determined price, if the exchange is closed then the market price is the closing price. The closing price of a stock is the price demanded by the seller and buyer at the end of the exchange day. Hutami (2012: 107) classified the valuation of stock into three types:

Wartoyo Hadi and Nurhayati. Analysis of The Effect of Net Profit Margin, Return on Assets, and Return on Equity on Stock Price (Case Study on Consumption Industrial Sector Companies Page : 82 Listed in Indonesian Sharia Stock Index at Indonesia Stock Exchange in 2016) 
1. Book Value is a calculated value based on the accounting of the stock issuer company. Book value is the asset value that remains after deducting the company's liability if shared.

2. Market Value is a formed price by request and supply of shares in the capital market, also called secondary market price. Market value is not effected by issuers or emission loans. This price represents the value of a company seen in the stock price at the stock exchange.

3. Intrinsic value is a stock value that determines fair a stock price so that the stock reflects the actual value of the stock. If the market value is greater than the intrinsic value (overvalued), then the stock is better on sale, but if the market value is smaller than the intrinsic value (undervalued), then the stock is better to buy.

\section{Profitability Ratios}

Kasmir (2017: 196) said that profitability ratios are a ratio to assess a company's ability to obtain profits and measure the level of management effectiveness of a company. The aim is to see the development of the company in a certain time, both decrease and increase, and find the cause of change. In this study three types of profitability ratios that used as follows:

1. Net Profit Margin

Kasmir (2017: 200) explained that NPM is a measure of profit by comparing earnings after interest and tax compared to sales. This ratio shows that the greater ratio is better because good company performance can generate large net income through its sales activitiy so that stocks are in great demand investors and increase stock prices.

\section{Return On Assets}

Kasmir (2017: 201-202) said that ROA is a ratio that shows the return on the amount of assets used in the company. ROA is used to see the level of effectiveness of the company's overall operations. The greater ratio is better because the company is considered capable of using its assets effectively to generate profits. Conversely a low or negative ratio indicates the ability of the capital invested as a whole assets have not been able to generate profits.

3. Return On Equity

Kasmir (2017: 204) explained that ROE is a ratio to measure net income after tax with own capital. The growth in ROE shows that the company's prospects are getting better because it has a potential to increase profits obtained by the company. ROE shows the efficiency of the use of own capital.

To review the effect of variables on stock price using a measuring instrument which consists of Net Profit Margin (NPM), Return on Assets (ROA), and Return on Equity (ROE), Earning Per Share (EPS), Book Value (BV), outlined in a framework as follows:

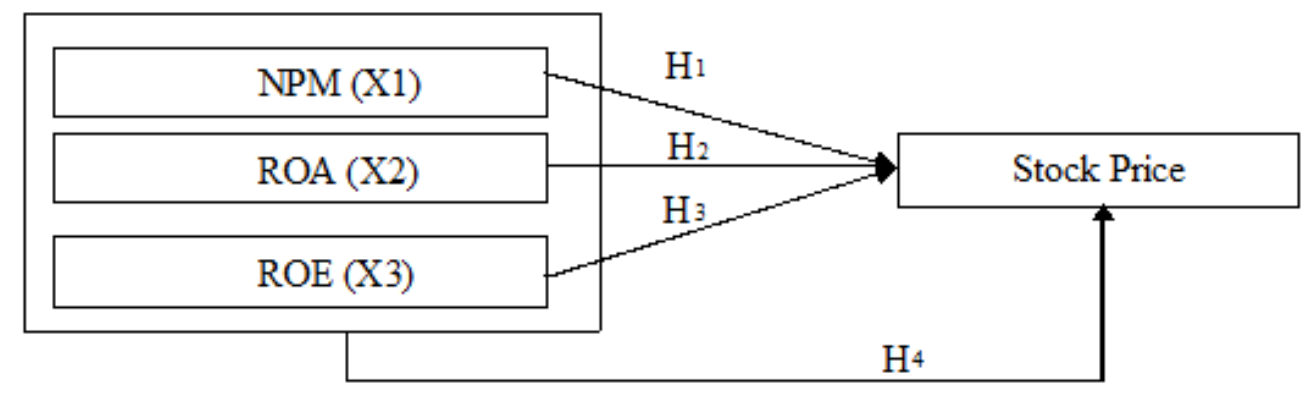

Figure1

Framework

Wartoyo Hadi and Nurhayati. Analysis of The Effect of Net Profit Margin, Return on Assets, and Return on Equity on Stock Price (Case Study on Consumption Industrial Sector Companies Listed in Indonesian Sharia Stock Index at Indonesia Stock Exchange in 2016) 


\section{RESEARCH METHODOLOGY}

\section{Research Methods}

The analytical method of data in this study is descriptive methods, Nazir (2005: 54) explained that descriptive method is a method of examining the status of a group of humans, an object, a set of conditions, a system of thought, or a class of events in the present. According to Saryono (2010), qualitative research is a study which used to investigate, find, describe, and explain the quality or privilege of social influences that cannot be explained, measured or described through a quantitative approach. In this study also explains the relationship, testing hypotheses, making predictions and getting the meaning and implications of a problem that you want to solve.

\section{Population and Sample}

The population in this study is companies in industry sector that listed in Indonesian Sharia Stock Index (ISSI) at Indonesia Stock Exchange in 2016 that recorded as 32 companies. The sampling technique that used in this study is purposive sampling. There are 31 companies that appropriate the criteria. The criteria in taking research samples are:

1. A company has audited financial statements as per December 31, 2016 and complete data required.

2. A company has data on closing stock prices as per December 31, 2016.

\section{Data Collection Method}

This research was conducted using documentation method. The research source is secondary data in the form of financial statements originating from the official website of Indonesia Stock Exchange www.idx.co.id .

\section{RESULTS AND REVIEW}

\section{Classical Assumption Test}

1. Multicollinearity Test

Ghozali (2006: 91) explained that multicollinearity test aims to test if there is a correlation of independent variables found in regression model. Common values used to indicate multicollinearity are tolerance values $<0.10$ or equal to VIF $>10$. Multicollinearity test results with regression as follows:

Table 1

Multicollinearity Test Results

\begin{tabular}{|c|c|c|c|}
\hline \multicolumn{4}{|c|}{ Coefficients $^{a}$} \\
\hline \multirow{2}{*}{\multicolumn{2}{|c|}{ Model }} & \multicolumn{2}{|c|}{ Collinearity Statistics } \\
\hline & & Tolerance & VIF \\
\hline \multirow[t]{4}{*}{1} & (Constant) & & \\
\hline & NPM & .286 & 3.492 \\
\hline & ROA & .105 & 9.514 \\
\hline & ROE & .203 & 4.929 \\
\hline
\end{tabular}

a. Dependent Variable: Stock Prices

Wartoyo Hadi and Nurhayati. Analysis of The Effect of Net Profit Margin, Return on Assets, and Return on Equity on Stock Price (Case Study on Consumption Industrial Sector Companies Page : 84 Listed in Indonesian Sharia Stock Index at Indonesia Stock Exchange in 2016) 
Based on Table 1, the Multicollinearity Test results show that there is no independent variable that has tolerance value less than 0.1 and VIF value more than 10. Tolerance value of NPM variable is 0.286 , ROA is 0.105 , and ROE is 0.203 . Whereas VIF value of NPM variable is 3.492 , ROA is 9.514 , and ROE is 4.929 . So it can be concluded that there is no multicolonity between independent variables in regression model.

\section{Autocorrelation Test}

Ghozali (2006: 95) explained that the autocorrelation test aims to observe if the linear regression model has a correlation between interfering errors in $\mathrm{t}-1$ period (previously). To detect there is autocorrelation by using Durbin Watson test (DW test) which is determined by the DW value. Criteria to make a decision with a significance level of $5 \%$ as follows:

$0<\mathrm{d}<\mathrm{dL} \quad$ : no positive autocorrelation

$\mathrm{dL} \leq \mathrm{d} \leq \mathrm{du} \quad$ : no positive autocorrelation

$4-\mathrm{dL}<\mathrm{d}<4 \quad$ : $\quad$ no negative and positive autocorrelation

$\mathrm{du}<\mathrm{d}<4-\mathrm{du}: \quad$ no positive or negative autocorrelation

Table 2

Autocorrelation Test Results

\begin{tabular}{|c|c|c|c|c|c|}
\hline \multicolumn{7}{|c|}{ Model Summary $^{\mathbf{b}}$} \\
\hline Model & $\mathrm{R}$ & R Square & $\begin{array}{c}\text { Adjusted R } \\
\text { Square }\end{array}$ & $\begin{array}{c}\text { Std. Error of } \\
\text { the Estimate }\end{array}$ & $\begin{array}{c}\text { Durbin- } \\
\text { Watson }\end{array}$ \\
\hline 1 & $.902^{\mathrm{a}}$ & .814 & .793 & 3312.91453 & 1.847 \\
\hline a. Predictors: (Constant), ROE, NPM, ROA & & \\
\hline \multicolumn{7}{|c|}{ b. Dependent Variable: Stock Price } & & \\
\hline
\end{tabular}

Based on Table 2, Autocorrelation Test results show Durbin Watson value AT 1.847 , this value which will be compared using Durbin Watson table value. In Durbin Watson table with the number of independent variables $(k)=3$ and the number of samples $(n)=31$ with a significance level of $5 \%$ get $\mathrm{dL}$ value $=1.229$ and $\mathrm{dU}=1.650$, then decided $d u<d<4$-du $(1,650<1,847<2,350)$ states that there are no positive or negative autocorrelations. It can be concluded that is $\mathrm{H}_{0}$ accepted which means there is no autocorrelation in the regression model.

\section{Heteroscedasticity Test}

Ghozali (2006: 105) explained that heteroscedasticity test aims to test whether in the regression model that variance inequality occurs from residual of one observation to another observation. To detect heteroscedasticity in this study using scatterplot graph.

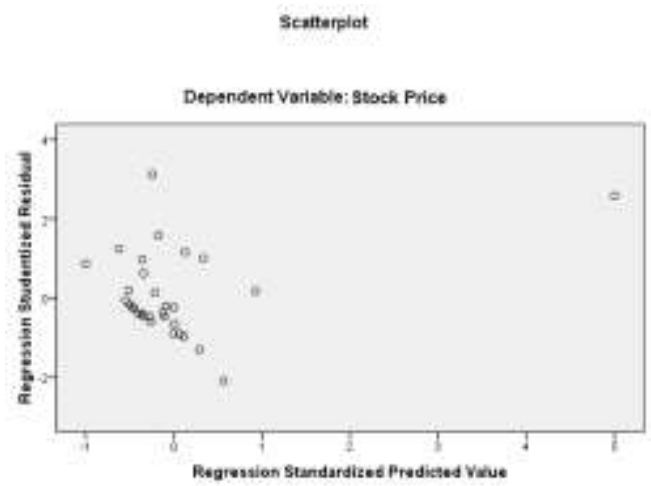

Figure 2. Scatterplot Graph

Wartoyo Hadi and Nurhayati. Analysis of The Effect of Net Profit Margin, Return on Assets, and Return on Equity on Stock Price (Case Study on Consumption Industrial Sector Companies Listed in Indonesian Sharia Stock Index at Indonesia Stock Exchange in 2016) 
In Figure 2 Scatterplot graph shows that the dots spread randomly above and below the number 0 on the $\mathrm{Y}$ axis. It shows that there is no clear pattern so that it can be concluded that heteroscedasticity does not occur.

4. Normality Test

Ghozali (2006: 110) explained that the normality test aims to find out if regression model, disturbing variable or residual has a normal distribution. Normality can be detected using Kolmogorov-Smirnov (K-S) non-parametric statistic test with a significant level of $\alpha=5 \%$, data normally distributed when asymptotic signifycance value $>0.05$. The results of kolmogorov-smirnov test as follows:

Table 3

\section{Normality Test Results}

One-Sample Kolmogorov-Smirnov Test

\begin{tabular}{|c|c|c|}
\hline & & Unstandardized Residual \\
\hline \multicolumn{2}{|l|}{$\mathrm{N}$} & 31 \\
\hline \multirow[t]{2}{*}{ Normal Parameters ${ }^{a}$} & Mean & .0000000 \\
\hline & $\begin{array}{c}\text { Std. } \\
\text { Deviation }\end{array}$ & 3142.90668681 \\
\hline \multirow[t]{3}{*}{ Most Extreme Differences } & Absolute & .152 \\
\hline & Positive & .152 \\
\hline & Negative & -.096 \\
\hline \multicolumn{2}{|c|}{ Kolmogorov-Smirnov Z } & .849 \\
\hline \multicolumn{2}{|c|}{ Asymp. Sig. (2-tailed) } & .467 \\
\hline
\end{tabular}

a. Test distribution is Normal.

Based on Table 3 the results of Normality Test seen that Kolmogorov-Smirnov value of 0.849 and Asymp value. Sig. (2-tailed) not significant at $0.05(0.467>0.05)$. So it can be concluded that is $\mathrm{H}_{0}$ accepted which means that residual data is normally distributed.

\section{Multiple Linear Regression Analysis}

Multiple linear regression analysis is an analysis tool to test the effect of two or more independent variables on one dependent variable. The results of multiple linear regression are as follows:

Table 4

Results of Multiple Linear Regression Analysis

Coefficients $^{a}$

\begin{tabular}{|c|c|c|c|c|c|c|}
\hline \multirow{2}{*}{} & \multicolumn{2}{|c|}{$\begin{array}{c}\text { Unstandardized } \\
\text { Coefficients }\end{array}$} & $\begin{array}{c}\text { Standardized } \\
\text { Coefficients }\end{array}$ & & \\
\cline { 2 - 5 } \multicolumn{2}{|c|}{ Model } & $\mathrm{B}$ & Std. Error & Beta & $\mathrm{t}$ & Sig. \\
\hline \multirow{3}{*}{1} & (Constant) & 621.284 & 789.230 & & .787 & .438 \\
\cline { 2 - 7 } & NPM & -117.375 & 117.111 & -.156 & -1.002 & .325 \\
\cline { 2 - 5 } & ROA & -8.478 & 186.896 & -.012 & -.045 & .964 \\
\cline { 2 - 5 } & ROE & 282.793 & 52.853 & .987 & 5.351 & .000 \\
\hline
\end{tabular}

a. Dependent Variable: Stock Prices

Wartoyo Hadi and Nurhayati. Analysis of The Effect of Net Profit Margin, Return on Assets, and Return on Equity on Stock Price (Case Study on Consumption Industrial Sector Companies 
Based on Table 4, Results of Analysis of Multiple Linear Regression can be expressed with mathematical equation as follows:

$Y=621,284-117,375$ NPM $-8,478$ ROA + 282,793 ROE

The regression equation can be seen that:

1. Constant value $(Y)$ of the equation above is equal to 621.284 indicates that stock prices are achieved if NPM, ROA, and ROE are considered constant. It means that when the three independent variables are ignored, the achievement of stock price is 621.284.

2. Regression coefficient of NPM (X1) as -117.375 shows that direction of change is inconstant, it means that if the other independent variables are constant, NPM rises by 1 unit, then the stock price will decrease by 117.375 .

3. ROA regression coefficient (X2) of -8.478 indicates that direction of change is inconstant, it means that if the other independent variables are constant, ROA increases by 1 unit, then the stock price will decrease by 8.478 .

4. ROE regression coefficient (X3) of 282.793 shows that direction of change is constant, it means that if the other independent variables are constants, ROE value increases by 1 unit, then the stock price will increase by 282.793

\section{Correlation Analysis}

Correlation analysis measures the strength of correlation between two variables through numbers called the correlation coefficient. Sugiyono (2010: 250) said that to give an interpretation of correlation strentgth, use the following guidelines:

$\begin{array}{ll}0,00-0,199 & : \text { very low correlation level } \\ 0,20-0,399 & \text { : low correlation level } \\ 0,40-0,599 & : \text { medium correlation level } \\ 0,60-0,799 & : \text { strong correlation level } \\ 0,80-1,000 & \text { : very strong correlation level }\end{array}$

Table 5

Correlation Analysis Results

Correlations

\begin{tabular}{|c|c|c|c|c|c|}
\hline & & Stock Price & NPM & ROA & ROE \\
\hline \multirow{3}{*}{$\begin{array}{c}\text { Stock } \\
\text { Price }\end{array}$} & Pearson Correlation & 1 & $.372^{*}$ & $.714^{* *}$ & $.892^{* *}$ \\
\cline { 2 - 6 } & Sig. (2-tailed) & & .039 & .000 & .000 \\
\cline { 2 - 6 } & $\mathrm{N}$ & 31 & 31 & 31 & 31 \\
\hline \multirow{4}{*}{ NPM } & Pearson Correlation & $.372^{*}$ & 1 & $.797^{* *}$ & $.544^{* *}$ \\
\cline { 2 - 6 } & Sig. (2-tailed) & .039 & & .000 & .002 \\
\cline { 2 - 6 } & $\mathrm{N}$ & 31 & 31 & 31 & 31 \\
\hline \multirow{3}{*}{ ROA } & Pearson Correlation & $.714^{* *}$ & $.797^{* *}$ & 1 & $.861^{* *}$ \\
\cline { 2 - 6 } & Sig. (2-tailed) & .000 & .000 & & .000 \\
\cline { 2 - 6 } & $\mathrm{N}$ & 31 & 31 & 31 & 31 \\
\hline \multirow{3}{*}{ ROE } & Pearson Correlation & $.892^{* *}$ & $.544^{* *}$ & $.861^{* *}$ & 1 \\
\cline { 2 - 6 } & Sig. (2-tailed) & .000 & .002 & .000 & \\
\cline { 2 - 6 } & $\mathrm{N}$ & 31 & 31 & 31 & 31 \\
\hline
\end{tabular}

*. Correlation is significant at the 0.05 level (2-tailed).

**. Correlation is significant at the 0.01 level (2-tailed).

Wartoyo Hadi and Nurhayati. Analysis of The Effect of Net Profit Margin, Return on Assets, and Return on Equity on Stock Price (Case Study on Consumption Industrial Sector Companies Listed in Indonesian Sharia Stock Index at Indonesia Stock Exchange in 2016) 
Based on Table 5, Correlation Analysis Results show the correlation between stock prices and NPM has a low correlation with a correlation coefficient of 0.372 . Stock prices and ROA have a strong correlation with a correlation coefficient of 0.714 . Whereas, stock prices and ROE have a very strong correlation with a correlation coefficient of 0.892 . NPM and ROA correlation coefficient values are 0.797 which indicates a strong correlation inter variables. NPM and ROA show a moderate relationship with a correlation coefficient of 0.544 . ROA and ROE have a very strong correlation with a correlation coefficient of 0.861 .

\section{Hypothesis Testing}

1. Individual Parameter Significance Test (t Test)

Ghozali (2006: 84) explains that the statistical test t basically shows how far the influence of one explanatory variable or independent partially in explaining the variation of the dependent variable. Decision criteria with $\alpha=0.05$ as follows:

If probability is> 0.05: $\mathrm{HO}$ accepted or Ha rejected If probability is $<0.05$ : Ha accepted or $\mathrm{H} 0$ rejected

Table 6

Results of Individual Parameter Test ( $t$ Test) Coefficients $^{\mathrm{a}}$

\begin{tabular}{|c|c|c|c|c|c|c|}
\hline \multirow{2}{*}{\multicolumn{2}{|c|}{}} & \multicolumn{2}{|c|}{$\begin{array}{c}\text { Unstandardized } \\
\text { Coefficients }\end{array}$} & $\begin{array}{c}\text { Standardized } \\
\text { Coefficients }\end{array}$ & \multirow{2}{*}{} & \\
\cline { 2 - 7 } \multicolumn{2}{|c|}{ Model } & B & Std. Error & Beta & T & Sig. \\
\hline \multirow{3}{*}{1} & (Constant) & 621.284 & 789.230 & & .787 & .438 \\
\cline { 2 - 7 } & NPM & -117.375 & 117.111 & -.156 & -1.002 & .325 \\
\cline { 2 - 7 } & ROA & -8.478 & 186.896 & -.012 & -.045 & .964 \\
\cline { 2 - 7 } & ROE & 282.793 & 52.853 & .987 & 5.351 & .000 \\
\hline
\end{tabular}

a. Dependent Variable: Stock Price

Based on Table 6, Individual Parameter Test Results (t Test) are concluded as follows:

a. The effect of NPM on stock prices obtained results of a significance value at $0.325>0.05$. So $\mathrm{H}_{0}$ is accepted. It means that NPM does not have a significant effect on stock prices.

b. The effect of ROA on stock prices obtained results in a significance value at $0.964>0.05$. So $\mathrm{H}_{0}$ is accepted. It means that ROA does not affect stock price.

c. The effect of ROE on stock prices results in a significance value of $0,000<0,05$. So $\mathrm{Ha}$ is accepted, which means ROE has an effect on stock price.

2. Simultaneous Test (F Test)

Ghozali (2006: 84) explained that F statistical test basically shows whether all independent or free variables included in the model have an effect on dependent or bound variable. Decision criteria with $\alpha=0.05$ as follows:

If probability is $>0.05: \mathrm{HO}$ is accepted or $\mathrm{Ha}$ is rejected If probability is < 0.05 : $\mathrm{Ha}$ is accepted or $\mathrm{HO}$ is rejected

Wartoyo Hadi and Nurhayati. Analysis of The Effect of Net Profit Margin, Return on Assets, and Return on Equity on Stock Price (Case Study on Consumption Industrial Sector Companies Listed in Indonesian Sharia Stock Index at Indonesia Stock Exchange in 2016) 
Table 7. Simultaneous Test Results (F Test) ANOVA $^{b}$

\begin{tabular}{|c|c|c|c|c|c|c|}
\hline \multicolumn{2}{|c|}{ Model } & Sum of Squares & Df & Mean Square & $\mathrm{F}$ & Sig. \\
\hline \multirow{3}{*}{1} & Regression & 1294855392.224 & 3 & 431618464.075 & 39.326 & $.000^{\mathrm{a}}$ \\
\cline { 2 - 8 } & Residual & 296335873.260 & 27 & 10975402.713 & & \\
\cline { 2 - 8 } & Total & 1591191265.484 & 30 & & & \\
\hline
\end{tabular}

a. Predictors: (Constant), ROE, NPM, ROA

b. Dependent Variable: Stock Price

Based on Table 7 Simultaneous Test Results (F Test) obtained the results of a significance value at $0,000<0,05$. Then $\mathrm{H} 0$ is rejected and $\mathrm{Ha}$ is accepted, it menas NPM, ROA, and ROE simultaneously affect stock price.

\section{Coefficient of Determination $\left(\mathbf{R}^{2}\right)$}

Ghozali (2006: 83) explained that coefficient of determination test $\left(R^{2}\right)$ basically measures how far the ability of model in explaining the variation of dependent variable. The limit of determination coefficient is $0<R^{2}<1$.

Table 8

Results of Determination Coefficient $\left(R^{2}\right)$ Model Summary ${ }^{\mathrm{b}}$

\begin{tabular}{|c|c|c|c|c|}
\hline Model & R & R Square & $\begin{array}{c}\text { Adjusted R } \\
\text { Square }\end{array}$ & $\begin{array}{c}\text { Std. Error of the } \\
\text { Estimate }\end{array}$ \\
\hline 1 & $.902^{\mathrm{a}}$ & .814 & .793 & 3312.91453 \\
\hline
\end{tabular}

a. Predictors: (Constant), ROE, NPM, ROA

b. Dependent Variable: Stock Price

Based on Table 8 Results of Determination Coefficient $\left(R^{2}\right)$, it is known that coefficient of determination (Adjusted $\mathrm{R}$ Square) is 0.793 . It means that variability of Stock Price variable can be explained by NPM, ROA, and ROE variables of $79.3 \%$, while the balance $20.7 \%$ is explained by other variables not included into regression model.

\section{Review of Study Results}

Based on the analysis results that described previously, then the review of study results as follows:

1. The effect of NPM on stock price based on study results obtained a significance value at $0.325>0.05$, so it is concluded that $\mathrm{HO}$ is accepted and $\mathrm{Ha}$ is rejected, it means that NPM does not affect stock price. The results of this study are in line with previous research by Putra et. al. (2014) who stated that stock closing price cannot be significantly affected by NPM with tcount value at 1.861 , with a probability at 0.068 $(p>0.05)$.

NPM used to measure profit margin on sales. Investors will pay attention to the level of net income generated through the company's sales activities when they will make a decision to invest. The increase in sales followed by an increase in indirect costs or a high tax burden will reduce the level of net income, so NPM presentation will decrease. It means that the company has failed in operational terms.

2. The effect of ROA on stock price

Based on the study results obtained a significance value at $0.964>0.05$, so it can be concluded that $\mathrm{HO}$ is accepted and $\mathrm{Ha}$ is rejected, it means that ROA does not affect stock price. The results of this study are in line with previous studies by Egam

Wartoyo Hadi and Nurhayati. Analysis of The Effect of Net Profit Margin, Return on Assets, and Return on Equity on Stock Price (Case Study on Consumption Industrial Sector Companies Listed in Indonesian Sharia Stock Index at Indonesia Stock Exchange in 2016) 
et. al. (2017) who stated that ROA has no effect on stock price with tcount value at $1.350<$ ttable at 2.004 and a significance value at $0.183>0.05$.

ROA is a ratio that shows the amount return of assets used by the company, both loan capital and own capital. Negative ROA is caused by company profits in negative or loss conditions. This shows the ability of capital invested as a whole assets have not been able to generate profits.

3. The effect of ROE on stock price

Based on the results of this study obtained a significant value at $0,000<0,05$ which can be concluded that $\mathrm{H}_{0}$ rejected and $\mathrm{H}_{a}$ accepted, it means that $\mathrm{ROE}$ has an effect on stock price. The results of this study are in line with previous research by Hutami (2012) who stated that ROE has a positive and significant effect on stock price with tcount $=6.256>\mathrm{t}$ table $=1.960$.

$\mathrm{ROE}$ is a ratio that shows efficiency in the use of own capital that indicates the condition of the company. It is important for investors because it shows the company's ability to manage capital from investors to get net income. With the increase in net income, ROE value will increase and attract investors to invest so that stock price will increase.

4. The effect of NPM, ROA, dan ROE simultaneouslyon stock price

Based on the results of this study obtained a significant value at $0.000<0.05$, so it can be concluded that $\mathrm{H}_{0}$ hypothesis rejected and is $\mathrm{H}_{4}$ accepted, it means that NPM, ROA, and ROE simultaneously effect stock price. Determination coefficient (R2) is 0.793 , it means that $79.3 \%$ of stock price variable can be explained by NPM, ROA, and ROE variables while the balance at $20.7 \%$ is explained by other variables outside the model. The results of this study are in line with a research which conducted by Sumaryanti (2017) who stated that ROA, EPS, NPM and ROE simultaneously have a significant effect on stock price with a probability value at $0.005<0.05$.

Investors can consider how the efficiency of a company earns income on net sales, income from the amount of assets used, and the ability to generate profits with its own capital. It was concluded that when NPM, ROA and ROE variables increased, it was ascertained that stock price would also increase. So that NPM, ROA, and ROE variables represent financial performance and can be important information for investors as a guide in predicting the company's stock price that is able to give benefits.

\section{CONCLUSION AND SUGGESTION}

\section{Conclusion}

1. Net Profit Margin (NPM) does not have a significant effect on Stock Price.

2. Return On Assets (ROA) does not have a significant effect on Stock Price.

3. Return On Equity (ROE) has a significant effect on Stock Price.

4. Net Profit Margin (NPM), Return On Assets (ROA), and Return On Equity (ROE) simultaneously have a significant effect on Stock Price in the Consumption Industry Sector Companies listed in Indonesian Sharia Stock Index (ISSI) at Indonesia Stock Exchange in 2016.

\section{Suggestion}

1. For the next researcher, it can add other variables that affect stock price, for example Debt Equity Ratio, Current Ratio, Devidend Per Share, Earning Per Share or Price to Earning Ratio. In addition, it can also multiply the sample and increase the period of the study so that it can obtain results that are more representative of the research subjects.

2. For investors, in predicting stock price can use financial statement analysis to describe the company's financial condition in the future. From the results of this

Wartoyo Hadi and Nurhayati. Analysis of The Effect of Net Profit Margin, Return on Assets, and Return on Equity on Stock Price (Case Study on Consumption Industrial Sector Companies Listed in Indonesian Sharia Stock Index at Indonesia Stock Exchange in 2016) 
study, ratio of Return on Equity, Net Profit Margin, and Return On Assets simultaneously have a significant effect in increasing stock price. So investors need to pay attention to these ratios in making decisions to invest.

\section{REFERENCE}

Andirerei. 2017. Sektor Apa Ya?. Diakses dari : http:/www.syariahsaham.com/ 2017/03/senarai-andirerei-sektor-apa-ya-bagian-1.html\#more. (16 Januari 2018)

Ardhian, Miftah. 2017. Kembangkan Pasar Saham Syariah, BEI Belajar ke Bursa Dubai. Diakses dari://googleweblight.com/?lite_url=https://katadata.co.id/berita/2017/10/30/kemban gkan-pasar-saham-syariah-bei-belajar-ke-bursa-dubai. (30 November 2017)

Asnawi, Said Kelana dan Candra Wijaya. 2015. FINON (Finance for Non Finance) Manajemen Keuangan untuk Non Keuangan. Jakarta: PT. Grafindo Persada.

Egam, G. E. Yermia, Ventje Ilat, dan Sonny Pangerapan. 2017. Pengaruh Return On Asset (ROA), Return On Equity (ROE), Net Profit Margin (NPM), dan Earning Per Share (EPS) terhadap Harga Saham Perusahaan yang Tergabung dalam Indeks LQ45 di Bursa Efek Indonesia Periode Tahun 2013-2015. ISSN 2303-1174. Jurnal EMBA Vol.5 No.1.

Fahmi, Irham. 2014. Manajemen Keuangan Perusahaan dan Pasar Modal. Jakarta: Mitra Wacana Media.

Ghozali, Imam. 2006. Aplikasi Analisis Multivariate dengan Program SPSS. Semarang: Badan Penerbit Universitas Diponegoro.

Hanum, Zulia. 2009. Pengaruh Return On Asset (ROA), Return On Equity (ROE), dan Earning Per Share (EPS) terhadap Harga Saham pada Perusahaan Otomotif yang Terdaftar di Bursa Efek Indonesia Periode 2008-2011. ISSN 1693-7619. Jurnal Manajemen \& Bisnis Vol. 08 No. 02.

Harmono. 2015. Manajemen Keuangan Berbasis Balanced Scorecard Pendekatan Teori, Kasus, dan Riset Bisnis. Jakarta: Bumi Aksara.

Hermawan, Asep. 2009. Penelitian Bisnis Paradigma Kuantitatif. Jakarta: [PT. Gramedia Widisarana Indonesia.

Hermawanti, Putri dan Wahyu Hidayat. 2016. Pengaruh Earning Per Share (EPS), Price Earning Ratio (PER), Debt To Equity (DER), Return On Asset (ROA), dan Return On Equity (ROE) terhadap Harga Saham Studi Kasus pada Perusahaan Go Public Sektor Property dan Real Estate yang Terdaftar di Bursa Efek Indonesia Tahun 2010-2014. Jurnal Ilmu Administrasi Bisnis Vol. 5 No. 3.

Hutami, R. Putri. 2012. Pengaruh Dividend Per Share, Return On Equity dan Net Profit Margin terhadap Harga Saham Perusahaaan Industri Manufaktur yang Tercatat di Bursa Efek Indonesia Periode 2006-2010. ISSN 2303-2065. Jurnal Nominal Vol. 1 Nomor 1.

Kasmir. 2017. Analisis Laporan Keuangan. Jakarta: PT. Rajagrafindo Persada.

Keown, Arthur J.,et al. 2017. Manajemen Keuangan: Prinsip dan Penerapan. Jakarta: PT. Indeks.

Wartoyo Hadi and Nurhayati. Analysis of The Effect of Net Profit Margin, Return on Assets, and Return on Equity on Stock Price (Case Study on Consumption Industrial Sector Companies Listed in Indonesian Sharia Stock Index at Indonesia Stock Exchange in 2016) 
Nazir, Moh. 2005. Metode Penelitian. Jakarta: Ghalia Indonesia.

Priatinah, Denies dan Prabandaru Adhe Kusuma. 2012. Pengaruh Return On Investment (ROI), Earning Per Share (EPS), dan Dividen Per Share (DPS) terhadap Harga Saham Perusahaan Pertambangan yang Terdaftar di Bursa Efek Indonesia (BEI) Periode 2008-2010. Jurnal Nominal Vol.1 No.1.

Putra,Y. Pratama, Moch. Dzulkiron A. R., dan Sri M. Rahayu. 2014. Pengaruh Return On Investment, Return On Equity, Net Profit Margin, dan Earning Per Share terhadap Harga Penutupan Saham Perusahaan (Studi pada Perusahaan Properti dan Real Estate yang Terdaftar di BEI Periode 2010-2012). Jurnal Administrasi Bisnis (JAB) Vol. 8 No. 2.

Rosyida, Ajeng Gama. 2015. Perbandingan Tingkat Pengembalian (Return), Risiko dan Koefisien Variasi pada Saham Syariah dan Saham Non Syariah di Bursa Efek Indonesia (BEI) Periode 2011-2013 . JESIT Vol. 2 No. 4.

Sangadji, Etta Mamang dan Sopiah. 2010. Metodologi Penelitian Pendekatan Praktis dalam Penelitian. Yogyakarta: Cv. Andi Offset.

Sekaran, Uma dan Roger Bougie. 2017. Metode Penelitian untuk Bisnis, Edisi 6. Jakarta: Salemba Empat.

Sugiyono. 2010. Metode Penelitian Bisnis (Pendekatan Kuantitatif, Kualitatif dan $R \& D$ ). Bandung: CV. Alfabeta.

Sumaryanti, T. Nonik. 2017. Pengaruh ROA, EPS, NPM \& ROE terhadap Harga Saham Perusahaan Sub-Sektor Batu Bara yang Terdaftar di Bursa Efek Indonesia. ISSN 2355-5408. eJournal Administrasi Bisnis Vol. 5 No. 2.

Sunaryo. 2011. Analisis Pengaruh ROA (Return On Assets), ROE (Return On Equity), Dan EPS (Earning Per Share) terhadap Harga Saham pada Kelompok Industri Barang Konsumsi yang Terdaftar di BEI (Bursa Efek Indonesia). BINUS NUSINESS REVIEW Vol. 2 No. 1.

Watung, R. Widiawati dan Ventje llat. 2016. Pengaruh Return On Asset (ROA), Net Profit Margin (NPM), dan Earning Per Share (EPS) terhadap Harga Saham pada Perusahaan Perbankan di Bursa Efek Indonesia Periode 2011-2015. ISSN 23031174. Jurnal EMBA Vol. 4 No. 2.

Widuhung, Sisca Debyola. 2014. Perbandingan Return dan Risiko Investasi pada Saham Syariah dan Emas. Jurnal AL-AZHAR INDONESIA SERI PRANATA SOSIAL Vol . 2 No. 3.

www.britama.com/index.php, accesed on January 15, 2018

www.idx.co.id, accesed on January 12, 2018

www.ojk.go.id, accesed on November 30, 2017

Yafiz, Muhammad. 2008. Saham dan Pasar Modal Syariah: Konsep, Sejarah dan Perkembangannya. MIQOT Vol. XXXII No. 2.

Wartoyo Hadi and Nurhayati. Analysis of The Effect of Net Profit Margin, Return on Assets, and Return on Equity on Stock Price (Case Study on Consumption Industrial Sector Companies Page : 92 Listed in Indonesian Sharia Stock Index at Indonesia Stock Exchange in 2016) 